\title{
A road to island sovereignty and empowerment? Fiji's aims within the Belt and Road Initiative
}

\author{
Adrien Rodd \\ Université de Versailles Saint-Quentin, France \\ adrien.rodd@uvsq.fr
}

\begin{abstract}
Though peripheral to China's policies of global engagement, the small island developing states (SIDS) of the Pacific are becoming an annex to Beijing's project for a 21stCentury Maritime Silk Road under the Belt and Road Initiative (BRI). Traditionally part of the West's exclusive sphere of influence, the Pacific Islands have become a contested space, seeking to benefit from the rivalries between the major powers. Among the foremost of these small island states is Fiji, whose Prime Minister Frank Bainimarama has enhanced Fiji's engagement with China. His government has sought to raise Fiji's profile on the international stage, seeking to be a regional power among the small states of the Pacific, and to carry the latter's voice and interests to global fora. Though on significantly different scales, both China and Fiji have embraced a form of 'go global' ambition. This paper examines the concrete and theoretical aspects of China's involvement in Fiji within the BRI and what Beijing and Suva each hope to achieve from this partnership. It will consider potential long-term trends, and whether this initiative may be empowering for Fiji and will discuss whether a SIDS can repurpose to its own advantage a much more powerful state's initiative, despite the latter's relative lack of interest in remote small island countries.
\end{abstract}

Keywords: Belt and Road Initiative, China, Fiji, islands, Small Island Developing States (SIDS), South Pacific, sovereignty

https://doi.org/10.24043/isj.128 • Received February 2020, accepted September 2020

(C) 2020-Institute of Island Studies, University of Prince Edward Island, Canada.

\section{Introduction: Sovereignty and small islands}

This paper approaches Fiji's participation in China's Belt and Road Initiative through the prism of the Fijian authorities' own perspectives, and through the prism of previous scholars' considerations on the nature and realities of the notion of sovereignty as applied to small island developing states (SIDS).

Legal definitions of sovereign statehood exist. Shaw (2017, p. 157) refers to the 1933 Montevideo Convention which defines as states those specific territories that have a permanent population subject to a government able to establish relations with other states (i.e., be recognised as a state within the international community). Using this as a starting point, Alberti and Goujon (2020, p. 9) propose "a set of six dimensions of sovereignty to characterize an organized political authority: diplomacy, executive, legislative, judicial, 
defence, and monetary." On this basis, they establish a gradient of the degrees of sovereignty of small island states and territories. Fiji scores a full "1" (on a scale from 0 to 1), having full and exclusive jurisdiction on all of the six identified dimensions of sovereignty.

Rayfuse and Crawford (2011, p. 5; emphasis added) add that "the requirement of 'government' [under the Montevideo Convention] is understood as the existence of an effective government, independent from the influence or control of other states." This is where neatly formal definitions of sovereignty may become blurred, as one might argue that no state is fully beyond the 'influence' of foreign states, particularly if we view 'influence' as being part of a realm of negotiated bilateral or multilateral relationships. For instance, a powerful state may provide development aid to a 'weaker' (small island developing) state with the explicit or implicit expectation of overt statements of diplomatic support in return. In such a case, the donor state certainly exercises 'influence' over the recipient SIDS's foreign policy, and the question arises as to the degree of choice the latter island state may have had in entering into this type of relationship, i.e., did the smaller state relinquish a small part of its sovereign prerogatives out of a (perceived) necessity for aid from that particular foreign power? This therefore also affects the fourth condition of statehood under the Montevideo Convention, the capacity to enter relations with other states, which Rayfuse and Crawford (2011) define as "the ability to operate as an independent entity on the global stage, able to engage in legal relations with other entities under international law." While the second part of that definition is not problematic, the degree to which a small state dependent on the good will of foreign powers may be said to "operate as an independent entity" in international diplomacy certainly is.

Murray and Overton (2011, p. 272) go so far as to argue that "in small Pacific Island states where the small size of government is coupled with increasing demands from donors for consultation, accountability and engagement [...], recipient states are actually losing control over their development strategies," and thus losing sovereignty by accepting donor states' requirements as to the framing and implementation of development means and goals. This point has been made by a number of scholars. Willcox (2012, p. 9) writes of SIDS that "their capacity to engage in international processes of negotiation is inevitably inferior to that of affluent developing states, with whom the primary decision-making power [...] lies." This lack of capacity is viewed as impeding these states' ability to fulfil one of the responsibilities of sovereignty - namely, the protection of the rights and interests of their respective peoples. Levine (2012, p. 445) concurs, highlighting the apparent paradox whereby "all Pacific Island countries are significant aid recipients, their independence, state apparatus and means of government all heavily subsidised by external sources." Implicitly, a 'subsidised' independence, i.e., an independence dependent in its most basic aspects on foreign goodwill, may be viewed as a shallow or conditional form of independence only. Herr (1988, p. 183) puts it more succinctly, believing that "the problem of small states is essentially one of sovereignty. [...] [Insular microstates] suffer the disadvantage of an asymmetrical power relationship with large states," whose conditional support is a prerequisite to any practical exercising of the functions of the smaller state's government.

This brings us to the point that formal or legal political sovereignty is contrasted with economic dependence, with the latter viewed as potentially undermining the reality of the former. From this point of view, one might argue that Alberti and Goujon's definition of degrees of sovereignty does not take into account constraints on sovereignty due to 
dependence on foreign powers for development, or even for the basic functioning of the state and the providing of essential services to the population. Pacific Island states' economic "vulnerability" is frequently highlighted. Henningham and Kovac (1995, p. 32) argue that Pacific SIDS face "economic [...] challenges to sovereignty .... [These] states, because of their small scale and lack of economic and [diplomatic] power, are subject to but have little influence over international political and economic trends." Their potential for economic growth and development depends on the interests of more powerful states, and on the global or bilateral rules that the latter set. Samoan scholar Te'o I.J. Fairbairn (2007, p. 133) notes that the question of the "economic vulnerability" of small island states has "become associated with such inherent attributes as smallness, peripherality, openness, paucity of natural resources and lack of structural diversification." He adds that "major components of economic vulnerability" generally assessed in quantitative indicators are "smallness, high trade dependence, remoteness, natural disasters and undiversified economic structures" (Fairbairn, 2007, p. 136). On such criteria, "the highest degree of vulnerability [...] is recorded by the very small states of Tuvalu, Kiribati, Comoros and Cape Verde," in contrast with "results for the larger SIDS such as Fiji, Jamaica and Papua New Guinea” (Fairbairn, 2007, pp. 133-136), which appear significantly less vulnerable due to a larger population, comparatively greater economic diversification, and a significantly lesser degree of geographic remoteness (in terms not simply of location but of connectedness) to major foreign markets. This contrast serves as a useful reminder that SIDS differ substantially in the degree (if not perhaps in the nature) of the challenges their development policies face by way of their 'inherent' characteristics of smallness and relative remoteness as islands or archipelagos, as well as their geographic vulnerability to climatic disasters.

If it is to have any practical meaning, the concept of 'economic dependence' supposes an inverse one, namely 'economic independence'. Grydehøj (2020, pp. 92-93), however, points out that "workable definitions of what 'economic independence' means on a state or territorial scale are [...] lacking" - perhaps because such a notion would be purely theoretical and detached from the realities of a globalised interdependent world. He notes that a "commonly accepted marker of economic dependence is an island's reliance on aid" from a foreign state, but warns that "because [small island states and territories] have proved particularly adept at accruing and attracting such transfers, it disproportionately harms [them] when these transfers are assessed as an illegitimate or unwanted source of income" (Grydehøj, 2020, pp. 92-93). From that perspective, if SIDS' 'inherent' characteristics as small archipelagos or islands mean they will continue to need aid transfers in the foreseeable future (Levine, 2012, p. 445), then the suggestion that aid 'dependence' chips away at sovereignty is unhelpful to these small states' exercising of their agency, or to their image in the eyes of partner states.

Indeed, small island states are not passive recipients but active agents exercising choice. Sharman (2017, p. 569), in an analysis of the applications of state independence within the international political framework in the early 21st century, argues that small states have few obligations with regard to the outside world but rather, by virtue of their legal status of sovereignty, "are presented with options," which they may navigate and choose from with significant latitude.

The present paper seeks to test that hypothesis within the scope of the Fijian government's choice to engage with China's Belt and Road Initiative (BRI). Does the BRI present risks to Fiji's sovereignty, as claimed for example by Australia's then-Foreign Minister 
Julie Bishop (Wroe, 2018)? Or might an increased but measured engagement with China's grand project in fact be sovereignty-enhancing for Fiji, if approached as part of a diversification of foreign relations?

As Fiji is foremost among the Pacific Island states in terms of engagement with China and with the broader world beyond the South Pacific, already possessing the economic and infrastructural means and the geographical advantages to serve as a 'hub' for its smaller neighbours in this regard, Szadziewski (2020, p. 9) argues that "Fiji's handling of [the] BRI's impact on its domestic spaces and policies is an indicator of how other states will reposition their promises of economic hope to civil society" - i.e., their public statements on the perspective of economic growth through BRI projects and capital. This could be particularly true of SIDS, facing similar needs to Fiji's as well as the prospect for greater engagement with China via Fiji's geographic hub, and potentially via the Fiji government's encouragement and mediation.

This paper will first provide an overview of Fiji's foreign policy in relation to China, and define Fiji's position within the (marginal) 'Southern Leg' of China's BRI. This essential framework having been laid out, the paper will then seek to answer the core question as to whether Fiji's government could use the BRI to attain practical sovereignty - defined here as sufficiently significant emancipation from dependence on key powers' development aid. In other words, although Fiji is de jure a sovereign state, its independence is de facto constrained by the priorities and requirements of the powerful partners it relies on to further its economic and human development. Bearing in mind the inherent difficulties which SIDS face in terms of affirming a meaningful degree of sovereignty (e.g., defining their domestic and foreign policies irrespective of the wishes of regional powers), might Fiji realistically be able to use the BRI as a means to diminish those constraints?

The author identifies four areas in which, from Fiji's perspective, the BRI is seen as a facilitator of the country's sovereignty: aiding Fiji's development; attracting other development partners to Fiji, while making the country overall more independent; enhancing Fiji's potential as a regional leader in the South Pacific; and facilitating Fiji's emergence and influence on the global stage. These four objectives, if actualised, would enable this Pacific Island state to exercise more fully the expected attributes of a sovereign state.

\section{Fiji's foreign policy}

Fiji faces a number of vulnerabilities and constraints common to SIDS, and these necessarily condition the aims and means of its foreign policy. Located thousands of kilometres from any wealthy market and out of the way of major trade routes, Fiji faces the costs born of remoteness in order to access profitable export markets. Its territory is an archipelago which comprises over a hundred inhabited islands, most of them tiny - the most remote of which, Rotuma, with a population of about 1,600 , is over $600 \mathrm{~km}$ away from Suva, the capital. This implies costs in the providing of essential, accessible services to such a scattered population of small island communities.

Fiji shares with other Melanesian countries the advantage of having a greater surface area, more fertile lands, and a greater volume of agricultural and mineral resources than most Pacific Island countries. But making the most of these resources requires significant investments and access to foreign markets. This has inevitably meant reliance and dependence 
on wealthier partners, particularly Australia, which has a strategic interest in ensuring the economic stability of its Melanesian neighbours.

Investments, infrastructural development, and easier access to a major market is precisely what Chinese's BRI is offering, as a complement to Western aid generally viewed as insufficient to help Melanesian and other Pacific Island societies progress towards robust economic growth and human development. Keshmeer Makun asserts:

The fact is that many of the PICs [Pacific Island countries] lack the physical infrastructure and supply chain logistics which can help them to export in a significant way. Considerable infrastructure investments in communications, seaports and airports are required to enhance trade and reduce the high cost of doing business and I think China's assistance through BRI to the Pacific region is helping substantially. (Zhang Y., 2019)

A key element in the attractiveness of the BRI for Fiji and other Pacific Island countries is therefore its comprehensiveness. It appears as a cohesive and coherent form of aid, connecting responses to different but interrelated development needs, all geared towards a clearly identified overarching aim - though, as we shall see, this may be little more than shallow appearance. Within the framework of the BRI, China promises to assist in "the development of interoperability of infrastructure to enhance air, land and sea connectivity among countries, including through interoperable and multi-modal transport," encompassing road, railways, shipping, aviation and "aerospace integrated information network" (Joint Communiqué, 2019).

Another key to the attractiveness of China's offers has been Beijing's care to emphasise environmental sustainability, in sharp contrast with Australia and the United States, both heavily criticized by Pacific Island leaders for refusing - under their current conservative governments - to engage in any meaningful way with the (literally) burning issue of climate change. In low-lying Pacific atolls, high tides and flooding due to the ocean warming have already led to internal displacements and have negatively affected the viability of small communities' livelihoods, in particular through saltwater contamination of freshwater reserves and of agricultural land. A great power pledging concrete action was bound to find a sympathetic ear in the South Pacific, particularly in the absence of an alternative.

China's promise to help develop "green finance" and "green technology" (Joint Communiqué, 2019) may of course sit uncomfortably with its own "notorious environmental record" (Pitlo, 2019) and its "carbon-intensive" policies within the BRI, with billions of dollars invested into foreign coal-power plants and other forms of fossil fuel production abroad (Nakano, 2019). But Xi Jinping's government, unlike Donald Trump's, at least talks the talk. Launched in April 2019, the Belt and Road International Green Development Coalition, which brings together some 115 countries, is undertaking to invest "trillions of dollars" into environmentally sustainable projects for "transport, energy, and telecommunications infrastructure, industrial capacity, and technical capacity building" - i.e., skills training in developing countries (United Nations Environment Programme, 2019). China is also "the world's largest producer of renewable energy," and has the capacity to share knowledge and technologies with other developing countries in terms of "off-grid solar systems, wind farms, and ocean wave energy" production (Pitlo, 2019). For such reasons, and because China still 
emphasises its status as a fellow developing country, Pacific Island leaders have proved willing to give China a pass, and not direct against China's heavy carbon footprint the same vocal criticism they address to Canberra and Washington (Harris, 2019). For now, at least, their attitude has been one of cautiously optimistic 'wait and see'.

Fiji's needs and priorities are thus similar to those of other Pacific Island countries albeit somewhat less urgent, in view of its comparatively more developed economy. But Fiji's recent history has also shaped its international outlook. In 2006, (indigenous) Commodore Frank Bainimarama, commander of Fiji's small military forces, ousted indigenous nationalist Prime Minister Laisenia Qarase, whom he accused of racial discrimination against the descendants of Indian migrants and, more generally (and quite accurately), of 'playing the race card' to stoke inter-ethnic tensions for political gain. Frank Bainimarama set up an 'interim' military dictatorship with a stated aim of fostering national unity and reshaping Fiji's democracy onto a non-racial basis.

Australia's and New Zealand's governments, unmoved by the new dictator's professed justification for his coup, imposed a range of sanctions on the country and sought -with little success - to encourage the broader international community to isolate the errant regime. Just a few months after Chinese Premier Wen Jiabao had visited Fiji for the first ever Economic Development and Cooperation Forum between China and the Pacific Island states, with Chinese investments in development projects in the Pacific Islands rising from about US \$40 million in 2005 to about US $\$ 280$ million in 2006 (Van Grieken \& Kantorowicz, 2019, p. 10), Frank Bainimarama enhanced his predecessor's 'Look North' policy by appealing to China to step up its trade and aid relationship with his country. China did so, effectively negating the economic and potential political consequences of Australian and New Zealand sanctions on Bainimarama's regime, and enabling the commodore to shrug off Western demands for a speedy return to democracy (Oosterveld, Wilms, \& Kertysova, 2018, p. 73).

Australia and New Zealand, aware of their sanctions having not only failed in their objective but diminished their own regional influence, finally lifted them and normalised their relations with Fiji after democratic elections in 2014 - carried out on an institutionally nonethnic basis - provided Prime Minister Bainimarama with the legitimacy of a clear parliamentary majority. Since then, however, China has remained one of Fiji's two primary aid partners. Between 2011 and 2017, Chinese aid to Fiji (some US\$317 million spent, out of US $\$ 380$ million committed) has been approaching that provided by Australia (US $\$ 408$ million spent) (Dayant \& Pryke, 2019) - although, as of 2017, Fiji's exports to Australia, New Zealand, and the United States were still worth 12 times more than its exports to China, its fifth largest export partner (Observatory of Economic Complexity, 2020). The Chinese government remains well aware of the circumstances of the expansion of its relations with Fiji, and has not hesitated to issue reminders thereof. During a speech in 2015 commemorating their forty years of formal diplomatic relations, Chinese ambassador to Fiji Zhang Ping (2015, p. 12) pointedly remarked:

China respects Fiji in choosing its own development path that suits its national conditions and supports Fiji in safeguarding its national dignity and pursuing economic development. [...] China stood steadfastly by the side of Fiji during its most difficult time. 
Beyond the implicit suggestion that Fiji's "most difficult time" was caused by Australia and New Zealand's paternalistic aggressiveness, the key notion here is that of respect. China portrays itself as recognising Fiji as a fully sovereign state with its own legitimate particularities, policies, and priorities, fundamental to its "dignity," in contrast to the West's disrespectful attempt to bully Fiji into a 'one-size-fits-all' political and policy model. The suggestion is that Western regional powers somehow view themselves as legitimately able to interfere in Fiji's internal affairs, while China would never do so. Such reminders from China, emphasising a sense of proximity, mutual understanding, respect, and shared interests, bear fruit. When Australia announced a 'step-up' in its relations with the Pacific at the Pacific Islands Forum in August 2019, Joseph Veramu, head of a Fijian think-tank on Asia, co-authored with the CEO of a Chinese-Fijian media company an article entitled 'BRI offers better path for Pacific than Australian way' in China's Global Times newspaper (Veramu \& Yang, 2019). They emphasised the usual positives that Chinese authorities themselves underline about the BRI: the BRI's incorporation of "tackling global warming issues" while Australia refuses to do so; tangible benefits expected in terms of economic growth; and China's greater respect for its partners. While the argument is obviously one sided, and tailored to please the editors of the medium it was published in, it does highlight practical reasons why Fiji has been drawn to China's offers.

In addition to the manner in which Fiji's recent history has influenced the country's foreign policy choices, Fiji's economic profile differs significantly from those of other Melanesian countries. For example, Papua New Guinea's great economic potential is severely hampered by its lack of transport, power, and other infrastructure, with around $85 \%$ of the population practicing subsistence or semi-subsistence lifestyles. The sheer scale of the funding required for infrastructural development needed to kick-start the modernisation of the country's economy is far beyond the government's means (Shen, 2018). The same is true of the Solomon Islands (still recovering from a near-collapse of state institutions and services at the start of this century) and Vanuatu, though on a somewhat smaller scale (Zhang D., 2019). By contrast, Fiji has attained a higher level of economic and human development than the other Melanesian states. In terms of the most basic infrastructure, in seeking to attract investors, Fiji highlights that all its cities and major towns are already interconnected by road, that fresh piped water is available almost all across the country, and that "almost all" Fijians have reliable access to electricity (Investment Fiji, 2019) - none of which is true in Papua New Guinea.

Fiji's profile, with a higher level of national GDP produced by the services sector than in other Pacific countries, the highest level of employment in that sector, and the lowest proportion of the population devoted to agricultural production, is that of a comparatively modern and sophisticated economy. Fiji is assessed by the United Nations Development Programme (2019) as having the highest level of human development among the developing countries of the Pacific. It far surpasses the other Melanesian nations in terms of average income and educational provision. It is one of only three sovereign developing Pacific Island states to be considered as having a high level of human development - the other two being its close neighbours Samoa and Tonga, which have much smaller populations and economies. Fiji's HDI ranking is only slightly behind China's - though in both countries, the overall figures naturally mask internal disparities in terms of individual opportunities and living standards, including between urban and remote rural areas. Indeed, almost a third of Fijians are deemed to be living in relative poverty - relative, for absolute poverty is rare in Pacific 
countries where subsistence agriculture, communal ownership of land, and strong indigenous cultural norms of community solidarity help alleviate cases of personal destitution.

These internal disparities notwithstanding, Fiji, far more than the other relatively large developing states of the Pacific, already possesses much of the infrastructure, skills, and manufacturing capacity needed for a comparatively modern and profitable export-focused economy. Unlike most other Pacific states "where even the basic infrastructure is rudimentary, Fiji has reasonably good physical facilities that can easily be upgraded and expanded" (International Business Publications, 2012, p. 46). While its Melanesian neighbours to the west need foreign aid merely to approach a level of economic sophistication that Fiji already possesses, and while its Polynesian neighbours to the east are too small (in terms of landmass, population, and resources) to engage meaningfully with global markets, Fiji is a step ahead. Thus, the economic benefits expected from its engagement with the BRI can fuel more substantial ambitions than those which other Pacific Island countries could realistically aspire to.

\section{Fiji and the South Pacific in the BRI}

Although it has been talked up for several years now, the BRI - a China-led policy framework for constructing inter-region trade and infrastructure networks - remains a new phenomenon in the southern Pacific islands. Indeed, the BRI is more a potentiality than an actualised coherent reality on the ground. This is in part because China has not viewed the region as a priority. In 2017, Denghua Zhang (2017, p. 1) wrote:

China is currently preoccupied with promoting cooperation with neighbouring states such as Pakistan, Cambodia, Myanmar, and central Asian countries in infrastructure connectivity. Given PICs' remoteness from China, their small population and limited economic potential, the Pacific could not be near the top of China's agenda, and China has not formulated plans to promote the Belt and Road initiative in the region.

A report by the Hague's Centre for Strategic Studies that same year made the same point, noting the lack of any "formal strategy" from China regarding the Pacific's integration into the BRI (Oosterveld, Wilms, \& Kertysova, 2018, p. 13). The BRI is intended to enhance, fluidify, and harmonise China's westward trade with its high-potential economic partners in Asia, East Africa, and Europe. The very notion of a 'new Silk Road' emphasises the upgrading of China's long-standing westward-facing trade, and serves also to legitimise it as a revival of China's historical, outward-looking golden age as an economic powerhouse. Not only does Fiji's small size mean it is not particularly economically attractive (despite its status as the most advanced economy among the developing countries of the South Pacific), but it also does not fit neatly into that 'Silk Road' narrative. In this regard, Yu Changsen (qtd. in Hannan \& Firth, 2016, p. 8) acknowledges Fiji and other Pacific Island countries' "geographical remoteness [and] lack of historical connection to China" as an explanation for their decidedly marginal status within the BRI project. 
Following the 2019 Belt and Road Forum in Beijing, which did not address any projects involving the Pacific, China's ambassador to Fiji, Qian Bo (qtd. in Vacala, 2019) candidly stated at the start of bilateral talks for a free trade agreement between China and Fiji:

The problem [...] is that many of our [sic] South Pacific countries are relatively small in size. When you want to export goods, one you have to ensure the quality, secondly you need to have the number - the quantity. If you have very small quantity and you export to China then it's meaningless. It will mean something for South Pacific Countries [but will be of little meaning to China].

The ambassador was seeking to emphasise the importance of Chinese assistance in helping Fiji adapt its export profile to the expectations of Chinese consumers, increase the volume of its output, and define a profitable marketing strategy. But his words are revealing of the gaping imbalance which makes China potentially very important to Fiji's future economic growth, at the same time as Fiji can never hope to be a meaningful trade partner for China. In fact, although it is now the main origin of foreign direct investments into Fiji, China "does not regard Fiji as a major destination of its FDI and has not even recorded its FDI in Fiji in its statistics yearbook" (Oosterveld, Wilms, \& Kertysova, 2018, p. 73). Fiji, it seems, does not even warrant being treated as an economic footnote.

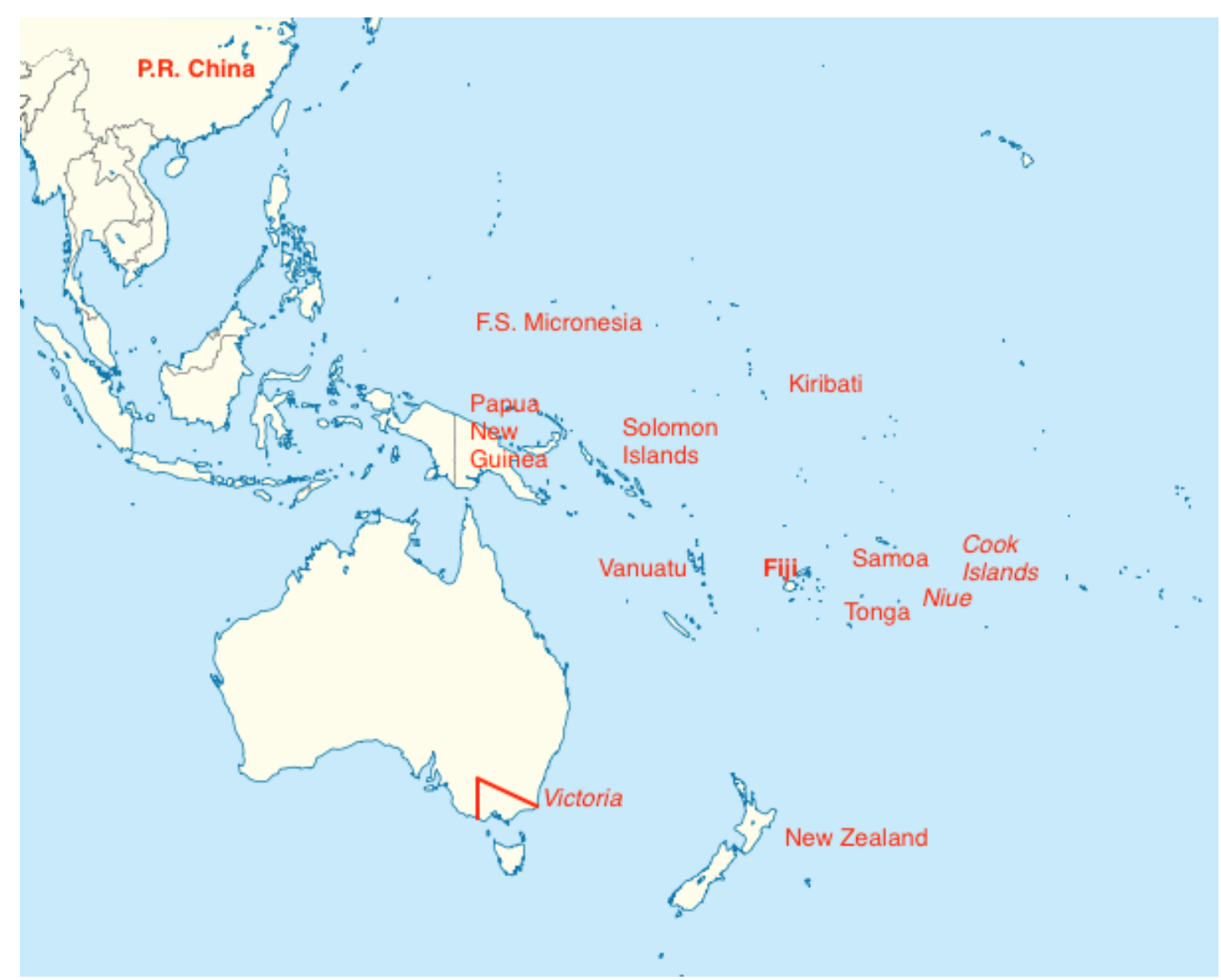

Figure 1: Signatories to the BRI in Oceania. China and Fiji are bolded. Non-sovereign states (the Cook Islands, Niue, and Victoria) are italicised. Source: Adapted from Night w, https://commons.wikimedia.org/wiki/File:Oceania full blank map.svg 
Formally, the South Pacific constitutes the far southern and eastern branch of the BRI's 21st-Century Maritime Silk Road and is referred to as its 'Southern Leg'. The 21st-Century Maritime Silk Road connects China's port cities for trade with southeast Asia (Vietnam, Malaysia, Indonesia), the Indian Ocean (India, Sri Lanka, Maldives), East Africa, and up through the Red Sea (Djibouti) and into the Mediterranean (Greece, Italy). Most maps of the 21st-Century Maritime Silk Road omit the South Pacific, which is de facto disconnected from the main 'Road' and instead connected to China separately.

Since 2017, China has signed a Memorandum of Understanding on Belt and Road Cooperation with nine of the 14 sovereign states of Oceania (New Zealand included), and with three non-sovereign states in the region (see Figure 1). While the Chinese authorities have not published a full list of signatory states, it has been possible to compile such a list by consulting websites of the Chinese embassies in these countries, reports by Chinese and other media, and statements from political leaders.

The practical purpose of BRI financing remains largely undefined, a form of vagueness designed to be reassuringly flexible and open to accommodating participant states' own evolving needs. That notion of empowerment is strengthened by the joint communiqué resulting from the leaders' roundtable of the second Belt and Road Forum in April 2019, in which China and signatory states emphasised "the importance of strengthening cooperation in human resources development, education, vocational and professional training, and build up the capacity of our peoples to better adapt to the future of work, so as to promote employment and improve their livelihoods." If put into practice, this would equip the peoples of developing states with the skills needed for their respective countries to become more selfsufficient, less dependent on foreign aid, and better equipped to benefit from engaging profitably in globalised trade. A more cynical reading, however, would note that existing and disparate projects can be subsumed under the new labelling of the BRI - repackaged in a way that bolsters China's image as a comprehensively supportive partner. In short, the BRI might be defined as encompassing anything and everything that China does to support signatory states, whether or not that amounts to a coherent and structured whole.

The protean ambiguity of this project has fuelled concerns, not least in Canberra, about China's mid- to long-term aims and intentions in the South Pacific region. China's investments in boosting the trade capacity of countries in south-eastern, southern, and western Asia are understood largely in economic terms, but as there is no "evident economic rationale" for China's involvement in most of the small developing countries of the Pacific (Papua New Guinea and Fiji excepted), "speculation about Chinese engagement has focused on political motives" (Oosterveld, Wilms, \& Kertysova, 2018, p. 5): wooing countries away from relations with Taiwan, or more generally gaining (buying) the diplomatic support of small island states which each have a voice and a vote in the United Nations General Assembly and other international fora. Commercial and aid dependence upon China could, some analysts have suggested, lead Pacific Island governments to "side with China" in such fora (Oosterveld, Wilms, \& Kertysova, 2018, p. 7), much as they previously avoided alienating their much-needed Western partners.

On the face of it, memoranda of understanding (MoU) on cooperation within the Belt and Road framework do not require participant states to align diplomatically with China. Fiji's MoU with China has not been made public, but Vanuatu's was leaked shortly after it was signed in 2018 and is thought to be identical (or near-identical) to those signed by other 
Pacific Island countries. Entering into immediate effect, it runs for a minimum of five years, after which either party may terminate it with three months' notice. Its provisions include: the two signatory countries, namely China and its Pacific Island partner, "will regularly communicate and promote the synergy and integration of their major development strategies, planning and policies" (Government of the Republic of Vanuatu \& Government of the People's Republic of China, 2018). They "will conduct cooperation and exchanges of infrastructure connectivity in areas of mutual interest, such as roads, bridges, civil aviation, ports and energy, telecommunications," "further open to each other, expand two-way investment and trade," and "explore mutually beneficial models of cooperation to support the implementation of major programs, such as infrastructure and production capacity alignment, etc.," making use of both public and private capital. None of this touches upon concrete policy implementation. It requires each Pacific country involved to open its market further to Chinese companies' products and investments, but along reciprocal lines which correspond with the SIDS' wishes. The requirement for "exchanges of infrastructure connectivity" may, however, be viewed as highly ambiguous; at a minimum, it would seem to require Pacific states to be open with China concerning the operation of their ports and telecommunications, and perhaps to allow partial Chinese shareholder control thereof, with a view to reconfiguring such infrastructure to facilitate their use in trading with China. The $\mathrm{MoU}$ also establishes that the parties will "settle differences in the interpretation and implementation of this Memorandum of Understanding through friendly consultations," which has no specific meaning whatsoever and could be interpreted by the more powerful of the two signatories (i.e., China) in any number of ways. Finally, it requires "the two Participants [to] respect the core interests and major concerns of each other," another extraordinarily vague provision. Euan Graham (qtd. in Walsh, 2018) sees that deliberate imprecision as intended to "become kind of a moral trap for the other party to avoid things that are seen as sensitive or which could offend China." Each Pacific state's government could then quietly be pressured, or even merely implicitly feel pressured, to exercise "selfcensorship" on controversial Chinese policies in Xinjiang, Tibet, or the South China Sea. Graham (qtd. in Walsh, 2018) describes this seemingly innocuous ambiguity as "exactly the kind of muddying of the waters that China wants to achieve in this, so that it has a broader geopolitical function to bind those countries." In short, these memoranda could lead gradually and insidiously to an assertion of hard Chinese influence over Pacific states' foreign policies.

The types of concern which have been expressed about the Belt and Road and its illdefined contents and implications in the South Pacific have been broad and numerous. Despite being supportive on balance of the BRI, Young (2017) highlights the initiative's vagueness as "an unanswerable question about what exactly [Pacific states] are committing to," and thus as an obvious source for concern. Given the power imbalance between signatories, there is a perceived risk that "what [they] are committing to" may be defined almost exclusively in Beijing rather than through bilateral discussion between equals. All the more so as the BRI, despite being touted as multilateral, has so far mainly taken the form of an unconnected set of bilateral memoranda, within which each individualised small state is hardly in a position to assert itself in the face of a partner it depends on. Other concerns include: 
- An enforced model in which recipient states are required to spend Chinese loans on providing contracts to Chinese companies using predominantly materials and labour imported from China (Oosterveld, Wilms, \& Kertysova, 2018, p. 49);

- The fact that these contractors are state-owned and thus accountable primarily to the instructions and requirements emanating from the Chinese government (Shen, 2018);

- Chinese aid undermining the stabilising effects of Western aid. As "China's approach [...] does not touch upon governance" (Young, 2017), Western governments have expressed concern that it might constitute a setback for Melanesian countries' progress towards institutional and economic stabilisation and growth - thus implicitly also maintaining them in a longer-term state of dependence towards China;

- Concerns about unsustainably high levels of borrowing from China's Export-Import Bank by some Pacific countries (though not Fiji) (Oosterveld, Wilms, \& Kertysova, 2018, p. 53);

- The diplomatic subordination of recipient countries: the editor of the Vanuatu Daily Post reported in 2018 that Chinese ambassador Liu Quan had explicitly told him China epectts Vanuatu's support and votes in international fora (Klan, 2018), laying bare the pretence at a partnership of equal sovereign states; and

- Concerns about China's geostrategic and possibly military intentions in the region, including speculation that China's upgrades to the wharf at Vanuatu's coastal town of Luganville might be designed to enable the establishment of a Chinese military base (Hillman, 2018), and about the possibility of a future Chinese military base in Fiji (Schleich, 2018, p. 8).

Many analysts, however, have dismissed as unsubstantiated the more extreme forms of criticism levelled at the BRI in the Pacific. Jason Young (2017) argues quite simply that China "has neither the hard power nor the soft power to become a genuine hegemon in the region," and that there is no evidence of a coherent attempt to be one on its part. Regarding the prospect of Chinese military 'creep' into the region, and in particular speculations about a possible future military base in Luganville, former Australian diplomat David Morris (2018) is bluntly dismissive, with a reminder that "Vanuatu is a proud member of the Non-Aligned Movement," highly unlikely to establish a military alliance with China against its own very close Australian neighbour, upon which it still depends for development assistance and trade. Vanuatu is a rational state actor, mindful of its own interests, which lie in maintaining diplomatic neutrality in its relations with its major partners. And, Kate Hannan and Stewart Firth write (2016, p. 14), there is every reason to believe that "military planners in Beijing take little if any interest in the Pacific Islands," having distinctly more pressing concerns within their own immediate neighbourhood. Regarding the notion of diplomatic subordination, Grieken and Kantorowicz's (2019, p. 15) quantitative study shows that "Beijing does not use state financing as a reward by providing more official financing to [Pacific Island countries] that vote with China in the UNGA," whereas it does reward countries in Africa and elsewhere that behave in this way. Grieken and Kantorowicz (2019, p. 21) also show "the lack of a statistically significant relationship between the types of official financing and the PICs' debt-to-GDP ratio suggests that China does not engage in aggressive lending" to insolvent Pacific Island countries which could thus be constrained to accept Chinese terms 
for debt relief, such as diplomatic alignment. They acknowledge that the paucity of quantitative data available makes it difficult to draw firm conclusions in this regard, but their data does suggest China shows little interest, at present at least, in subordinating Pacific countries to its will through aid dependency - perhaps not least because those countries are far less interesting partners than China's Asian neighbours or than countries in East Africa. They would thus simply attract less Chinese attention and effort.

That still leaves the question of what China's interests and objectives in the region may be, if we dismiss the obligatory official line that Beijing is motivated solely by a sense of selfless generosity and moral obligation. Leaving aside also purely economic considerations, which are less applicable in parts of the South Pacific than in Asia, a number of analysts have concluded that China's involvement in the Pacific may be primarily about a minor boost to its own national image. As Wade (2016) puts it, the "great revival of the Chinese nation" promoted by President Xi Jinping - not least for domestic political purposes- "requires a restored global position and identity for China." Indeed, President Xi Jinping's (2017) words to the congress of the Communist Party in 2017 defined "the Chinese Dream of national rejuvenation" as one in which Chinese people will "create a better life for themselves and ultimately achieve common prosperity for everyone," in "an era that sees China moving closer to centre stage and making greater contributions to mankind." Enhancing relations with small island states in the Pacific is obviously not essential to that goal, but may constitute a useful addition to China's increased role across Asia, in Europe and in Africa. Peter Cai (qtd. in Walsh, 2018) therefore argues that having a country like Fiji or Samoa sign a memorandum of cooperation with China on the BRI "just gives the Chinese Government a sense of a diplomatic, symbolic victory - a foreign country has ascribed to an important foreign policy initiative of the Chinese President." To put it more bluntly, Chinese loans and investments which have caused such concern in Australia might be, above all else, "a marketing exercise, rebranding everything that China does abroad under slogans that flatter Mr. Xi's global pretensions" (The Economist, 2018). In which case, the frustrating and sometimes worrisome vagueness of the BRI's meaning in the South Pacific would be explained not by the fact that it is designed to conceal darker purposes, nor even that it is intended to ensure a form of flexibility responsive to Pacific Islanders' needs, but rather that the shallow labelling matches a hollow content. Chinese development assistance to the Pacific is real, of course, but perhaps the 'Belt and Road Initiative' is more of a nametag added to existing and future ad hoc projects than the start of a more cohesive and comprehensive development approach.

\section{The BRI as a means for Fiji's attainment of practical sovereignty?}

What does this mean for Fiji's participation in the project? If Fiji is (to put it mildly) marginal to China's global outlook, of barely incidental use either to China's international standing or to its economic growth, might the BRI nonetheless be of genuine use to Fiji, on both a symbolic and (more significantly) practical level? As Davis, Munger, and Legacy (2020, p. 5) remark, though the BRI's "constellations of material infrastructures aim to orient islands" towards functions consonant with China's interests, "these facilities can be redesigned or redirected toward other places and purposes" through the agency of recipient island states. The current paper identifies four areas in which the BRI, and Fiji's relations with China more generally, may be seen as beneficial to Fiji through Suva's own appropriation and reshaping 
of what the initiative offers. First, practical assistance towards Fiji's economic development and the country's capacity to autonomously grow its own economy in the future. Second, the manner in which China's involvement indirectly increases other development partners' assistance to Fiji, while de facto enabling Fiji to assert greater strategic independence. Third, Fiji's intention to make use of the BRI to enhance its own role as a regional hub, and as a country essential to the rest of the South Pacific. Fourth, and perhaps most interestingly, Fiji's ambition to repurpose the BRI as a facilitator for Fiji's own emergence and influence on the global stage - albeit on a modest scale. These four areas are explored below.

\section{Aiding Fiji's development}

Although the full text of Fiji's Memorandum of Understanding with China within the framework of the BRI has not been published, Fijian Minister for Industry, Trade, and Tourism Premila Kumar spoke of its content in early 2019, thereby confirming that it covers the same themes and uses the same very general language as memoranda signed by other states: "cooperation [on] infrastructure connectivity," a deepening of bilateral trade and investments, "synergy and integration of major development strategies," and so on (Talei, 2019). She also mentions ongoing or completed projects which she presents as having been conducted as part of the BRI: Chinese loans to assist in the building of two new bridges in Suva; a civic centre in Suva renovated thanks to a Chinese loan; the building of a "state of the art sports facility" (Talei, 2019) for a high school; and the training in China of 149 Fijians in professional fields including agriculture, teaching, and information technology.

Although Fiji had formally signed up to the BRI just three months earlier, and all of these projects had merely been retroactively labelled as part of the BRI, Fiji's government was able to present them as a concrete foretaste of further benefits to come. Other recent practical forms of assistance from China have included work on a hydropower station on the small island of Taveuni; upgrading the highway to the port of Nabouwalu on Vanua Levu, Fiji's second biggest island; providing Fiji with dozens of school buses, ambulances, and police cars; providing technical expertise on rice and mushroom cultivation (Oosterveld, Wilms, \& Kertysova, 2018); the ongoing construction of two bridges; the donation of agricultural machines and the provision of training for improved rice cultivation (Brant, 2016); improvements to Fiji's rural power grid; loans for the building of low-cost housing; and the sending of Chinese doctors to Fiji "to provide free medical services to the local people" (Zhang P., 2015). The three most expensive foreign-funded aid projects in Fiji between 2011 and 2016 were all carried out by Chinese companies, "upgrading" or "improving" road networks for a total cost of US $\$ 245$ million (Dayant \& Pryke, 2019). While these are mostly small-scale projects, the government views their intended cumulative effect as encouraging. And as "the tourism industry's combined direct and indirect contributions to GDP averaged above 30.0 percent" prior to the COVID-19 pandemic (Reserve Bank of Fiji, 2017), far more than in poorer Pacific countries which lack a meaningful tourism industry, China's visa exemption agreement with Fiji in 2015 and investments in Fiji's tourism sector were a simple but effective way to help grow Fiji's economy: the number of Chinese tourists visiting Fiji grew by 72\% between 2014 and 2017, with China becoming "the fourth largest source market of tourists" to the country (Oosterveld, Wilms, \& Kertysova, 2018, p. 75). China now accounts for over 40\% of foreign investments in Fiji (Wang, 2017), and as of 2017 - i.e., before the formalisation of a BRI agreement - bilateral trade between the two countries was 
reportedly growing at 12\% per annum (Young, 2017). Which, in view of the mismatch between the sizes of the countries' economies, was of little meaning to China but of significant economic value to Fiji.

This practical aid may quite correctly be seen as merely the product of Fiji's pre-existing bilateral relationship with China, and not as an implementation of the BRI. So far, the 'BRI' label has mainly be applied to projects already begun, and figures are not yet available to determine whether there has been a significant increase in Chinese investments and aid in 2018 and 2019. But by going along with China's labelling of this development assistance, Fiji's government evidently hopes to entrench China's commitment to infrastructural development and training.

Attracting other development partners to Fiji, while making Fiji more independent

This is an indirect effect of China's involvement. As Fijian economist Keshmeer Makun puts it, "China's presence and assistance has [...] motivated our regional neighbours such as Australia, New Zealand and U.S. to step up [and make] commitments to boost the Pacific region's development” (qtd. in Zhang Y., 2019). Australia's 'Pacific Step-up' announced in 2016, for example, includes an Australian Infrastructure Financing Facility for the Pacific (AIFFP), established in 2019 at a cost of AU $\$ 2$ billion. In short, competition for influence between foreign powers in the Pacific has enabled Fiji to reap practical benefits from rival powers' offers. While China claims not to wish to compete against the West in the region, Australia has been open about its own need to heighten its perceived usefulness to Fiji and others in order not to lose diplomatic ground in the one part of the world where it can act as a regional power. Fiji thereby attracts significantly more assistance from the West (Australia, New Zealand, the US, the EU) and Japan than it would have done had China not become one of its major development partners. While Australia, Japan, and the United States' embryonic plan for a 'Blue Dot Network' for joint infrastructural development assistance to countries of the Asia-Pacific may still be undefined, if actually implemented in spite of the COVID-generated economic downturn in donor countries, "it is expected [to] offer similarly-sized loans as the BRI, but with much lower interest rates" (Cook, 2018). This would place Fiji in the relatively luxurious position of being able to pick and choose, to its own benefit and in accordance with its own chosen criteria, between investments and loans offered by China or by its rivals, in effect upping the ante so as to obtain more substantial commitments from the West. One concrete example has already been seen: when China offered to help upgrade Fiji's Black Rock military base at Nadi, Australia successfully stepped in with a more tempting offer, which Fiji duly chose. The Republic of Fiji Military Forces' chief of staff for co-ordination, Captain Eroni Duaibe, explains:

Let me put it this way: the development of Black Rock has been backlogged for quite some time now due to financial restraints. China had had an interest in that for quite a while but [...] Australia played their cards right .... [China were] asking us to do certain parts of the development while they come in as a partner to do other developments. But when Australia placed the offer on the table, it was holistic development of Black Rock, not only of the infrastructure development but also the provisions of personnel and training of our troops and providing that expertise in various areas. (qtd. in Riordan, 2018) 
In effect, Australia is seeking to purchase regional influence in a suddenly less favourable market, and Fiji, by having chosen previously to accept assistance from China, has placed itself in a position to be able to set its terms and price - to a certain extent. The capacity to decline assistance from a great power and choose to cooperate with another instead, without alienating the former in the process, has strengthened Fiji's sovereignty, freeing it from a constraining dependence upon one particular partner. All the more so as Fiji has not traded deference towards one partner for deference to another. This was demonstrated in 2016 when the Chinese government publicly asserted Fiji's support for its territorial claims in the South China Sea. Unlike Papua New Guinea and Vanuatu, which have indeed toed Beijing's line on the issue, the Fijian government swiftly issued a denial. The Fijian Ministry of Foreign Affairs' statement included a firm reminder of "our policy of strict non-alignment," emphasised Fiji's "friendly relations with all countries bordering the South China Sea," and called for "strict adherence to [...] international law" in the South China Sea (Delaibatiki, 2016). Beijing, contrary to its own apparent assumption, had not bought Fiji's diplomatic support - partly because Fiji wishes indeed to maintain friendly and beneficial relations with countries like Malaysia involved in the South China Sea territorial dispute, and partly because the diversification of its development partners enables Fiji to feel confident enough to assert its diplomatic independence in relation to China - as well as in relation to Australia.

\section{Enhancing Fiji's potential as a regional leader in the South Pacific}

In addition to being the most developed and wealthiest per capita state among the small island countries of the Pacific, Fiji has benefited from its central geographic location, and has long been the transit hub for airline travel between other Pacific Island countries. For that reason, it has also long been the host of regional organisations. The Pacific Islands Forum, historically the main forum for regional cooperation, is based in Suva, as is the main campus of the international University of the South Pacific. The United Nations Development Programme's office for the South Pacific is in Suva, as is the Asian Development Bank's. It therefore had the potential for a significant role within the region, which Frank Bainimarama's government sought to actualise after Australia and New Zealand attempted to marginalise the country in the wake of the 2006 military coup. Their efforts succeeded in seeing Fiji temporarily suspended from the Pacific Islands Forum, thus persuading the then-military regime of the need to strengthen its intra-regional relations. In recent years, Fiji has sought to make itself an important and valued partner to poorer, generally smaller countries in the South Pacific. Fiji is now an aid donor to several Pacific Island states, and has signed its own bilateral 'memoranda of understanding' to assist in the development of Vanuatu, the Solomon Islands, the Federated States of Micronesia, Kiribati, the Marshall Islands, Nauru, and Tuvalu (Wallis, 2017, p. 14). Prime Minister Bainimarama's launch in 2013 of a de facto Fiji-led Pacific Islands Development Forum to rival the Pacific Islands Forum (PIF) demonstrated Fiji's capacity to attract Chinese funding for a project aimed at undermining Australian regional leadership: the PIDF was mainly funded by China (Bryant-Tokalau, 2018, p. 26). Though it has failed to eclipse the PIF, it remains a statement of Fiji's (China-enabled) ambition.

Since 2013, Fiji has also provided 'training assistance' to the military forces of Papua New Guinea - a country much larger but far less developed and per capita much poorer. Fiji's intention is to raise the capacity of Papua New Guinea's military in order to enable a regional defence partnership, organised around joint security provision by Fiji and Papua New 
Guinea to their smaller neighbours (Wallis, 2017, p. 18) - a step towards replacing Australia's regional role in this regard. Indeed, Suva's stated aim is to promote and facilitate Pacific Island states' overall and gradual autonomy from Australia, New Zealand, and any other "external powers," by helping them wean themselves off dependence in certain areas. Implicitly, this would of course empower Fiji itself, as its very small neighbours would in fact still lack the potential for genuine autonomy, and would shift from dependence on external powers to relative dependence on a Fiji-centred, specifically Oceanic cooperation network.

Fiji aims to act as a mediator of sorts in relations between individual Pacific Island states and their development partners such as Australia, China, the United States, France, or Japan. Fijian authorities have referred to these as 'triangular' or 'trilateral' partnerships: external powers would be welcome to support Fiji's bilateral assistance to each small Pacific Island developing state, providing additional "know-how and resources" but in a manner respectful of the "development goals and ideals" decided upon bilaterally by that small state and Fiji (Mawi, 2015, pp. 6-11). By choosing Fiji as a primary development partner, Pacific countries would, in Fijian diplomat Litia Mawi's (2015, pp. 6-11) words, benefit from "the lower costs and greater appropriateness of skills and expertise available in Fiji" compared with those proposed by countries beyond the region: they would also be following the path of Fiji's successful strengthening of its own practical (as opposed to merely de jure) independence; the Fijian government offers explicitly to "develop the capacities of smaller PSIDS [Pacific SIDS] who wish to take [the] sovereignty route" that Fiji itself has travelled. Fiji would thus make itself the indispensable partner to the development of poorer Pacific Island countries, in part by supplying direct assistance and expertise, and in part by acting as the guarantor that the weaker country's priorities are respected. And China, at least, has appeared to take a step in Fiji's direction, with the Chinese embassy in Suva speaking of engaging in "trilateral cooperation" with Fiji in the Pacific (Qian, 2019). This strikingly ambitious intention has, however, yet to become a meaningful reality.

That notwithstanding, Prime Minister Bainimarama (qtd. in Zhang Q., 2017) has described the BRI as "complementary" to his country's regional ambition, with Fiji hoping to benefit from Chinese infrastructural assistance and "to pass it [on to] the rest of the South Pacific region," as Fiji would be the "regional transportation hub" connecting smaller Pacific economies' trade to China. In this regard, China's promise to take climate change seriously has encouraged Fiji to welcome Beijing's regional involvement - but, here too, very much on Fiji's own terms. Speaking at the High-Level Forum on South-South Cooperation on Climate Change, convened at the China Pavilion at the COP24 (Conference of the Parties to the United Nations Framework Convention on Climate Change) in Poland in December 2018, Frank Bainimarama (2018) expressed his support for the BRI, but urged China to focus it more meaningfully and more rapidly on environmentally sustainable development:

China's Belt and Road Strategy is a massive investment in infrastructure in the future global economy that we in the Pacific welcome. We very much hope that a principal focus of this strategy will be to help us all develop net zero emission and more climate resilient economies and societies. [...] We trust that this effort can be scaled up as time progresses. [...] It has taken [China] perhaps too long to realise it but [they] have now placed themselves on a cleaner, more sustainable footing. The technologies they are developing for themselves - such as the convergence between 
renewable energy, storage and electrification of transport - can be offered to other countries in the south and I very much hope that happens on a sizeable scale as the years progress.

This was bold talk from the leader of a small developing country with a population of fewer than a million - scolding the world's rising power, praising it for having learnt from its mistakes and urging it to continue to do better. But Fiji, empowered by its expanding partnership options, and seeking to build up its regional influence by positioning itself as a strong voice for the climate interests of other small Pacific states, was clearly setting out the terms by which China could grow its own status and influence in this one region of the developing world - a region for which Fiji is appointing itself guardian and spokesperson.

Facilitating Fiji's emergence and influence on the global stage

Needing to expand its commercial and diplomatic partners as a result of Australian and New Zealand sanctions in the late 2000s, Fiji's then-military government embarked upon the most active policy of international engagement ever attempted by a Pacific Island country. It went from holding formal diplomatic relations with 70 countries in 2009 to 178 in 2020. In the early 2010s, Fiji opened embassies in South Korea, Indonesia, South Africa, Brazil, and the United Arab Emirates (Government of Fiji, 2012a). Fiji has also stepped up its relations with Malaysia (where it has had a high commission/embassy since 1989), India, and Japan. In 2016, Fiji also opened an embassy in Ethiopia, with Fiji's Foreign Affairs Minister Ratu (Chief) Inoke Kubuabola noting (2016) that Ethiopia is "strategically placed" in geographical terms, host to several regional and international organisations, and that it was thus "fitting for Fiji to be present in Ethiopia in order to reach to the rest of Africa."

Fiji's foreign policy under Frank Bainimarama's government has grown into one that specifically seeks to have Fiji recognised as an active and meaningful partner in the affairs of the developing world. Hence the country joining the Non-Aligned Movement in 2011 (only the third Pacific Island country to do so, after Vanuatu and Papua New Guinea), building up its bilateral ties with BRICS countries (Mawi, 2015, pp. 4-5) viewed as key leaders of the developing world, and hosting the 2019 meeting of ASEAN Finance Ministers despite Fiji not (yet) being a member of ASEAN. One of the Fijian government's biggest achievements in this regard was its successful candidacy to chair the United Nations' 'Group of 77' (G77), the association of 132 developing countries cooperating to collectively defend their shared economic interests in the world's main international forum, for the year 2013. As leader of the first ever Pacific Island country to preside over the world's foremost coalition of developing countries, Prime Minister Bainimarama had good reason to express and encourage a sense of pride among Fijians (Government of Fiji, 2012b):

We have been given the honour of presiding over the deliberations of an important bloc of nations in the world, including the world's most populous country, China. We truly have something to celebrate - that our small island nation is so well regarded in the community of developing countries that they have decided to place us at the top, to chair their meetings. 
Chairing the G77 enabled Fiji to develop sustained contact with the diplomats and leaders of the world's most influential developing countries, not least China. Suva also sought to use this chairing experience to further raise Fiji's legitimacy and usefulness as a leading partner and role model within the South Pacific, and vice-versa to invoke Fiji's development assistance to Pacific Island states as a means to demonstrate "to the international community" - and particularly to fellow developing states - "Fiji's distinctive brand of responsible global citizenship" (Mawi, 2015).

In Fiji's view, China and the BRI have a role to play in building up Fiji's international activism and broadened partnerships. With China having encouragingly stated that it "supports Fiji in playing a positive role in international and regional affairs" (Zhang P., 2015), Fiji's President (ceremonial head of state) Jioji Konrote told Chinese ambassador Zhang Ping in 2017 that "Fiji views the Belt and Road Initiative as a connector [...] that will facilitate our connection to the global community" (Xiang, 2017). From that perspective, rather than being an annex of little importance at the tail end of the BRI's 21st-Century Maritime Silk Road, Fiji would seek to use the BRI not only to increase its commercial and diplomatic relations with China but also with other BRI participant states, across Asia and indeed all the way to East Africa - despite the fact that the BRI is currently organised as a series of bilateral relationships with China, rather than as a multilateral network. This ties in with President Xi's (2018) statement, in a letter published in Papua New Guinea's Post-Courier newspaper in 2018, "the BRI will open up new pathways for Pacific island countries to enhance business ties and connectivity with China, among themselves and with the rest of the world," with China implicitly acting as a hub or gateway to "connect" these countries to other foreign markets, investors and partners. As the sole leader of a Pacific Island country to attend the Belt and Road Forum in Beijing in 2017, Frank Bainimarama (2017) presented himself there as "a voice for Pacific Island nations and small island states on the issue of climate change." Since then, his government has repeatedly emphasised China and the BRI's significance in helping Fiji mobilise the international community's efforts on climate change, to the benefit of SIDS.

Fiji attained its most prominent and most active international role when it chaired the COP23, the 2017 United Nations Climate Change Conference, tasked mainly with laying the groundwork for an assessment mechanism for states' progress towards implementing the Paris Agreement reached at the COP21 in 2015, but also with integrating key non-state actors into that implementation. China not only reaffirmed its intention to meet its targets under the Paris Agreement, thus providing great-power impetus on climate change at a time when the United States had made clear its intention to withdraw from its commitments, but also provided Fiji with over US $\$ 100,000$ to help fund the chairing of the conference (Radio New Zealand, 2016). Frank Bainimarama also seized the opportunity of the 2017 Belt and Road Forum "to meet with other world leaders and discuss the agenda" (Zhang Q., 2017) of the COP23 due a few months later - an indirect but useful opportunity provided by the BRI. China's refusal to support Fiji's call to increase states' commitments to a higher level than what they had pledged in Paris (Voïta, 2017) did not cause significant friction, but did demonstrate that, for all its activism, Fiji remains a small country unable to effectively promote global action except with the support of major powers - and lacks leverage to apply to those powers' foreign policies.

Beyond the COP23, the Fijian government has nonetheless suggested that the BRI may align with, and thus help to advance, Fiji's own efforts towards regional and international 
sustainable development. If the BRI can be, as Frank Bainimarama has called for, "a model of green finance" (Pratibha, 2017), then it may yet enable Fiji to enhance at least its own regional influence in the South Pacific, building 'trilateral' relationships in which Fiji's expert advice to its smaller neighbours would be backed with BRI funding. Chinese diplomats in Fiji have been supportive in principle (Zhang P., 2017), though large-scale concrete action is yet to follow.

\section{Conclusion}

What we have witnessed from Fiji's unprecedentedly active foreign policy over the past decade might be described as "Fiji's rise as a 'normal' state. In terms of international relations, this means that Fiji has gained the capacity and willingness to act at the international level to support its interests and shape global affairs" (O’Keefe, 2015, p. 9). Under Prime Minister Bainimarama's long-established leadership (he has now been in power for over 13 years, and the next general election is not due until late 2022), the initial motivator for that policy was a combination of Fiji's already initiated 'Look North' policy towards the growing economies and markets of Asia, the country's stark need for new partners in the face of Western sanctions, and the coincidental beginning of China's meaningful involvement in the southern Pacific. Arguably alone among the SIDS of the Pacific, Fiji had the pre-existing capacity to turn necessity into opportunity, emancipating itself from excessive economic dependence on Australia - and thus from the weight of Australian influence - so as to enhance its own diplomatic independence through a diversification of partnerships, rather than suffer the pitfall of dependence upon China instead. For now at least, Fiji has the luxury of choosing between, and thus in some cases turning down, offers of development assistance from rival powers. This has also given it the capacity to assert a genuinely independent voice on the international stage, to some extent asserting its own conditions for its partnerships with countries far more powerful than itself.

Chinese loans for development projects in Fiji had begun several years before Fiji signed a 'Memorandum of Understanding on Belt and Road cooperation' with China in November 2018. The BRI so far has mainly been a label applied retroactively to existing projects, and a series of (sometimes frustratingly) vague statements about grander and overall more cohesive things to come. It is "still in its infancy" (Zhang D., 2017, p. 1) and, in countries of comparatively little economic or strategic interest to China, may turn out to be nothing more than a marginal quantitative increase in Chinese infrastructural investments and training programmes, wrapped in grand talk of win-win cooperation and greener futures. As a small developing state, Fiji's opportunities are not entirely in its own hands, and depend partly on what China decides (perhaps on a largely unilateral basis) to make of the BRI, and partly on whether Australia and its allies (Japan, the United States, etc.) continue to attempt to "up the ante' by outbidding China to Fiji's benefit.

What appears certain is, first, that the risks which foreign observers have associated with the BRI present relatively little danger to Fiji. The country's public debt is diversified and sustainable. Suva has firmly stuck to a policy of sovereign non-alignment, refusing to provide diplomatic support to China in the South China Sea dispute, and is supremely unlikely to accept any Chinese military base on its territory, even if Beijing were interested in having one. Fiji's credibility and influence in its ambitious global role rest on maintaining a clear 
image of its own strategic independence. Second, and in line with Beijing's oft-repeated claim that the BRI will be defined through bilateral (and multilateral) cooperation partnerships, Fiji will certainly attempt to shape the framing and content of the BRI, notably as a "model of green finance" and as a participant in Fiji-mediated 'trilateral' partnerships, not only for its own continued development but for that of the South Pacific in general.

It is in this regard that the BRI may prove most relevant to Fiji. If the Fijian government can demonstrate a capacity to orient practical BRI projects towards the concrete needs of SIDS (assuming the BRI is not scaled back or reoriented away from the Pacific as a result of the COVID-19 pandemic's economic impact), then China's BRI may serve as a springboard for Fiji's ability to mobilise great power support towards the sustainable development of Suva's own partners - and thus raise Fiji's status as a (distinctly minor but secure and independent) local power in its own right. Such is already Fiji's ambition.

\section{References}

Alberti, F., \& Goujon, M. (2020). A composite index of formal sovereignty for small islands and coastal territories. Island Studies Journal, 15(1), 3-24. https://doi.org/10.24043/isj.96

Bainimarama, J.V. (2018, December 3). Hon. PM Bainimarama at the launch of Fiji's National Adaptation Plan. Fijian Ministry of Foreign Affairs.

http://www.foreignaffairs.gov.fj/component/content/article/39-speeches/2018minister-speeches/1140-hon-pm-bainimarama-at-the-high-level-forum-on-southsouth-cooperation-on-climate-change

Bainimarama, J.V. (2017, May 15). People to people bond. Fijian Ministry of Foreign Affairs. http://www.foreignaffairs.gov.fj/about-us/27-speeches-2017/926-hon-pm-speechat-belt-road-forum

Brant, P. (2016). Chinese aid in the Pacific. Lowy Institute. https://chineseaidmap.lowyinstitute.org

Bryant-Tokalau, J. (2018). Indigenous Pacific approaches to climate change: Pacific Island countries. Palgrave Macmillan. https://doi.org/10.1007/978-3-319-78399-4

Cook, E. (2018, September 7). South Pacific waking to China's 'debt-trap' diplomacy. The Asia Times. https://asiatimes.com/2018/09/south-pacific-waking-to-chinas-debttrap-diplomacy/

Davis, S., Munger, L.A., \& Legacy, H.J. (2020). Someone else's chain, someone else's road: U.S. military strategy, China's Belt and Road Initiative, and island agency in the Pacific. Island Studies Journal, 15(2), 13-36. https://doi.org/10.24043/isj.104

Dayant, A., \& Pryke, J. (2019). Pacific aid map. Lowy Institute. https://pacificaidmap.lowyinstitute.org

Delaibatiki, N. (2016, April 16). Clearing the air on our position on the South China Sea. The Fiji Sun. https://fijisun.com.fj/2016/04/16/clearing-the-air-on-our-positionon-the-south-china-sea/

The Economist (2018, July 26). China has a vastly ambitious plan to connect the world. What is behind the Belt and Road Initiative? The Economist. https://www.economist.com/briefing/2018/07/26/china-has-a-vastly-ambitiousplan-to-connect-the-world 
Fairbairn, T.I.J. (2007). Economic vulnerability and resilience of small island states. Island Studies Journal, 2(1), 133-140.

Government of Fiji. (2012a, July 19). Fijian Prime Minister opens embassy in South Korea. Media Centre - News. http://www.foreignaffairs.gov.fj/media-publications/mediarelease/45-fijian-prime-minister-opens-embassy-in-south-korea

Government of Fiji (2012b, September 29). Fiji elected to chairmanship for G77. Media Centre - News. https://www.fiji.gov.fj/Media-Centre/News/FIJI-ELECTEDTO-CHAIRMANSHIP-FOR-G77

Government of the Republic of Vanuatu \& Government of the People's Republic of China. (2018, November 9). Memorandum of understanding between the Government of the Republic of Vanuatu and the Government of the People's Republic of China on cooperation within the framework of the Silk Road Economic Belt and the 21st century Maritime Silk Road.

Grydehøj, A. (2020). Unravelling economic dependence and independence in relation to island sovereignty: The case of Kalaallit Nunaat (Greenland). Island Studies Journal, 15(1), 89-112. https://doi.org/10.24043/isj.101

Hannan, K., \& Firth, S. (2016, June). 'One belt one road': China's trade and investment in Pacific Island states. International Studies Association. http://web.isanet.org/Web/Conferences/AP\%20Hong\%20Kong\%202016/Archive/ 72aa134d-b73e-4a8d-9dcf-d9fc8adf9f96.pdf

Harris, R. (2019, August 16). China's Pacific climate pitch angers Australia, US. Sydney Morning Herald. https://www.smh.com.au/politics/federal/china-s-pacific-climatepitch-angers-australia-us-20190816-p52hxa.html

Herr, R. (1988). Microstate sovereignty in the South Pacific: Is small practical? Contemporary Southeast Asia, 10(2), 182-196.

Hillman, J. (2018, May 16). Clouds gathering around China's Belt and Road. Nikkei Asian Review. https://asia.nikkei.com/Opinion/The-clouds-gathering-around-China-sBelt-and-Road2

International Business Publications (2012). Fiji company laws and regulations handbook (vol. 1). International Business Publications.

Investment Fiji (2019, December). Key infrastructure services. http://www.investmentfiji.org.fj

Joint Communiqué of the Leaders' Roundtable of the 2nd Belt and Road Forum for International Cooperation. (2019, April 27). Belt and Road Cooperation: Shaping a Brighter Shared Future.

https://www.fmprc.gov.cn/mfa eng/zxxx 662805/t1658766.shtml

Klan, A. (2018, January 31). Chinese envoy tells Vanuatu it expects support in return for aid. The Australian. https://www.theaustralian.com.au/nation/foreignaffairs/chinese-envoy-tells-vanuatu-it-expects-support-in-return-for-aid/newsstory/44fd8ded4a475a2a247e54d9dcf46344

Kubuabola, I. (2016, May 26). Foreign Minister Kubuabola officially opens Fiji's mission in Addis Ababa. Embassy of the Republic of Fiji to Ethiopia. http://www.foreignaffairs.gov.fj/media-publications/media-release/880-ministerkubuabola-officially-opens-fiji-mission-in-addis-ababa 
Levine, S. (2012). The experience of sovereignty in the Pacific: Island states and political autonomy in the twenty-first century. Commonwealth \& Comparative Politics, 50(4), 439-455. https://doi.org/10.1080/14662043.2012.729729

Mawi, L. (2015). Fiji's emerging brand of Pacific diplomacy: A Fiji government perspective. In G. Fry \& S. Tarte (eds.), The new Pacific diplomacy (pp. 101-109). Australian National University Press. https://doi.org/10.22459/NPD.12.2015.09

Morris, D. (2018, December 26). Australia-China geopolitics and the South Pacific. China Focus. http://www.cnfocus.com/australia-china-geopolitics-and-the-south-pacific/

Murray, W.E., \& Overton, J. (2011). The inverse sovereignty effect: Aid, scale and neostructuralism in Oceania. Asia Pacific Viewpoint, 52(3), 272-284. https://doi.org/10.1111/j.1467-8373.2011.01468.x

Nakano, J. (2019, May 1). Greening or greenwashing the Belt and Road Initiative? Center for Strategic \& International Studies. https://www.csis.org/analysis/greening-orgreenwashing-belt-and-road-initiative

O'Keefe, M. (2015). The strategic context of the new Pacific diplomacy. In G. Fry \& S. Tarte (eds.), The new Pacific diplomacy (pp. 125-136). Australian National University Press. https://doi.org/10.22459/NPD.12.2015.11

Observatory of Economic Complexity. (2020). Country Profile: Fiji. https://oec.world/en/profile/country/fji

Oosterveld, W., Wilms, E., \& Kertysova, K. (2018). The Belt and Road Initiative looks East: Political implications of China's economic forays in the Caribbean and the South Pacific. The Hague Centre for Strategic Studies.

Pitlo, L.B. III. (2019, November 15). China's Pacific challenge. The Diplomat. https://thediplomat.com/2019/11/chinas-pacific-challenge/

Pratibha, J. (2017, November 17). PM highlights contribution by Global South on development. The Fiji Sun. https://fijisun.com.fj/2017/11/17/pm-highlightscontribution-by-global-south-on-development/

Qian, B. (2019, April 28). Belt and Road Initiative: Brighter shared future for all. The Fiji Sun. https://fijisun.com.fj/2019/04/28/belt-and-road-initiative-brighter-sharedfuture-for-all-including-fiji/

Radio New Zealand. (2016, December 15). China helps fund Fijian presidency at COP 23. https://www.rnz.co.nz/international/pacific-news/320477/china-helps-fund-fijianpresidency-at-cop-23

Rayfuse, R., \& Crawford, E. (2011). Climate change, sovereignty and statehood [Legal Studies Research Paper No.11/59]. Sydney Law School.

Reserve Bank of Fiji (2017, July 16). Fiji's Tourism Industry. Reserve Bank of Fiji. https://www.rbf.gov.fj

Riordan, P. (2018, September 7). Australia beats China to funding Fiji base. The Australian. https://www.theaustralian.com.au/nation/defence/australia-beats-china-to-fundingfiji-base/news-story/60d05ca8eb2bec629080c2c844255bbd

Schleich, A.M. (2018, June). Geopolitical trends in the South Pacific: Is the US or China winning? ISPSW Strategy Series, 554, 1-10.

Sharman, J.C. (2017). Sovereignty at the extremes: Micro-states in world politics. Political Studies, 65(3), 595-575. https://doi.org/10.1177/0032321716665392 
Shaw, M.N. (2017). International law (8th ed.). Cambridge University Press.

Shen, Y. (2018, November 14). China and Papua New Guinea relations forging ahead with great opportunity. China Focus. http://www.cnfocus.com/china-and-papua-newguinea-relations-forging-ahead-with-great-opportunity/

Szadziewski, H. (2020). Converging anticipatory geographies in Oceania: The Belt and Road Initiative and Look North in Fiji. Political Geography, 77. Epub ahead of print. https://doi.org/10.1016/j.polgeo.2019.102119

Talei, F. (2019, February 13). 5 key areas of interest: MOU between Fiji and China. The Fiji Sun. https://fijisun.com.fj/2019/02/13/5-key-areas-of-interest-mou-betweenfiji-and-china/

United Nations Development Programme (2019). Human development report 2019. UNDP.

United Nations Environment Programme (2019). The Belt and Road Initiative International Green Development Coalition (BRIGC). https://www.unenvironment.org/regions/asia-and-pacific/regional-initiatives/beltand-road-initiative-international-green

Vacala, K. (2019, May 13). Free Trade Agreement talks underway between Fiji and China. Fiji Broadcasting Corporation. https://www.fbcnews.com.fj/news/free-tradeagreement-talks-underway-between-fiji-and-china

Van Grieken, B., \& Kantorowicz, J. (2019). Debunking myths about China: The determinants of China's official financing to the Pacific. Geopolitics. Epub ahead of print. https://doi.org/10.1080/14650045.2019.1654459

Veramu, J., \& Yang, M.H. (2019, August 25). BRI offers better path for Pacific than Australian way. The Global Times. https://www.globaltimes.cn/content/1162610.shtml

Voïta, T. (2017, December 1). Changement climatique: la Chine règne-t-elle désormais sur les COP? Asialyst. https://asialyst.com/fr/2017/12/01/changement-climatiquechine-regne-cop/

Wade, G. (2016). China's 'One Belt, One Road' initiative. In D. Heriot (ed.), Parliamentary Library Briefing Book - 45th Parliament (pp. 148-151). Parliament of Australia.

Wallis, J. (2017). Crowded and complex: The changing geopolitics of the South Pacific. Australian Strategic Policy Institute.

Walsh, M. (2018, December 1). China's Belt and Road initiative and just what it means to sign on. Australian Broadcasting Corporation. https://www.abc.net.au/news/2018-1201/china-belt-and-road-what-does-it-mean-when-countries-sign-on/10562374

Wang, K. (2017, May 13). Belt and Road Initiative gives Fiji a tourism boost. China Global Television Network. https://news.cgtn.com/news/3d41544f31677a4d/index.html

Willcox, S. (2012). A rising tide: The implications of climate change inundation for human rights and state sovereignty. Essex Human Rights Review, 9(1), 1-19.

Wroe, D. (2018, June 18). Australia will compete with China to save Pacific sovereignty, says Bishop. The Sydney Morning Herald.

https://www.smh.com.au/politics/federal/australia-will-compete-with-china-tosave-pacific-sovereignty-says-bishop-20180617-p4zm1h.html 
Xi, J. (2018, November 14). Set sail on a new voyage for relations between China and Pacific Island countries. Post-Courier. https://postcourier.com.pg/set-sail-newvoyage-relations-china-pacific-island-countries/

Xi, J. (2017, November 4). Secure a decisive victory in building a moderately prosperous society in all respects and strive for the great success of Socialism with Chinese Characteristics for a New Era. Xinhua. http://www.xinhuanet.com/english/download/Xi Jinping's report at 19th CPC National Congress.pdf

Xiang, B. (2017, October 12). Fiji lauds China-proposed Belt and Road Initiative. Xinhua. http://www.xinhuanet.com/english/2017-10/12/c 136675215.htm

Young, J. (2017, March 11). Realising the southern leg of the Maritime Silk Road. Guangdong Institute for International Strategies. https://giis.gdufs.edu.cn/info/1356/7424.htm

Zhang, D. (2019, October 18). Perceiving China's influence in the Pacific: The case of Solomon Islands. The Diplomat. https://thediplomat.com/2019/10/perceivingchinas-influence-in-the-pacific-the-case-of-solomon-islands/

Zhang, D. (2017). Pacific Island countries, China \& sustainable development goals, Part 2: The Belt and Road Initiative. In Brief, 2017(18). http://dpa.bellschool.anu.edu.au/experts-publications/publications/5488/ib201718pacific-island-countries-china-sustainable

Zhang, P. (2017, May 14). Closer co-operation under Belt and Road win-win for Fiji, China. The Fiji Sun, 12.

Zhang, P. (2015, November 6). To create a new splendid future of China-Fiji relationship. Chinese Ministry of Foreign Affairs.

https://www.fmprc.gov.cn/mfa eng/wjb 663304/zwjg 665342/zwbd 665378/t13 13067.shtml

Zhang, Q. (2017, May 12). B\&R Initiative brings new opportunities for the South Pacific:

Fiji PM. China Radio International.

http://chinaplus.cri.cn/news/china/9/20170512/4484.html

Zhang, Y. (2019, March 17). Interview: Fijian expert sees Belt and Road Initiative development dividend for participating countries. Xinhua. http://www.xinhuanet.com/english/2019-03/17/c 137901848.htm 
Adrien Rodd 